\title{
A Portrait of John Adams as a Young Man: The 1970s Juvenilia
}

James Joyce draws on musical language when describing one of the moments leading up to Stephen Dedalus's aesthetic epiphany on the Dollymount shore in A Portrait of the Artist as a Young Man: "He heard a confused music within him as of memories and names which he was almost conscious of but could not capture even for an instant; then the music seemed to recede, to recede, to recede: and from each receding trail of nebulous music there fell always one longdrawn calling note, piercing like a star the dusk of silence." ${ }^{11}$ Such imagery of confused music, comprising sound, memories, and names from the past, appearing and receding in the creative consciousness of an artist desperate to forge an identity, seems particularly apt when describing young composers. ${ }^{2}$ The narrative trajectory from youthful inexperience to artistic maturity in A Portrait of the Artist as a Young Man shares similarities with the nonfictional early career of John Adams as he experimented with differing compositional styles between 1971 and 1976. During this phase of Adams's career, both popular music and the avant-garde influenced his creative consciousness. The result was an erratic sequence of aesthetic shifts as Adams tried out differing stylistic conventions and compositional techniques from influential composers, seeking a potential path

Michael Palmese graduated with his PhD in musicology and a minor in comparative literature at Louisiana State University. His research interests encompass music and art from the twentieth and twenty-first centuries, particularly minimalism and postminimalism. In addition, he focuses upon Samuel Beckett's intersections with music, politics and music, and aesthetics of the Viennese fin de siècle. His other articles and reviews have appeared in Journal of Beckett Studies, Nineteenth Century Music Review, Tempo, Samuel Beckett Today/Aujourd'hui, and Irish Studies Review. He recently contributed a chapter to the 2017 edited collection Arvo Pärt's White Light: Media, Culture, Politics (Cambridge University Press). 
forward. Although Adams especially sought to align himself with Cage's notions of indeterminacy and chance between 1971 and 1976, he eventually found himself at an impasse not only with Cage but also with the entire avant-garde. Years later, he could recall: "I took Cage seriously in his admonishment about keeping the ego out of the music. But I wasn't happy about it. I could feel a restlessness and lingering dissatisfaction with the avant-garde position. . . . I didn't see much difference between a work created American-style by tossing coins and one created Euro-style by transposing serial sets of pitches." ${ }^{3}$ This article examines this previously unstudied phase of the composer's creative life through detailed studies of four works. It shows that Adams modeled his early music on influential avant-garde pieces and sometimes emulated their sound worlds before the arrival of his "official opus one" in 1977: a pair of piano pieces entitled China Gates and Phrygian Gates that he describes as illustrating the "fruits of my initiation to Minimalism."4

The article begins with Heavy Metal, an electronic work composed by Adams in 1971 as a graduate student at Harvard University and one sharing stylistic correspondences with works by Cage, Karlheinz Stockhausen, and William Burroughs. Hockey Seen, written in 1972, is a forty-minute electronic piece for a multimedia dance project sponsored by Harvard University. This lengthy composition exhibits a conflation of avant-garde influences that include sound spatialization, musique concrète elements, and minimalist drones and repetition. Ktaadn, composed between 1972 and 1974, is a choral piece that employs indeterminacy. While Cage's influence remained a crucial factor, Adams also availed himself of minimalist conventions, from the modular scoring style of Terry Riley to modal pitch collections. "Christian Zeal and Activity," the second movement of American Standard, written between 1972 and 1973, draws compositional influences from such contemporaries as Cornelius Cardew, Christian Wolff, and Gavin Bryars.

\section{"Heavy Metal" (1971)}

Heavy Metal, completed in 1971, is a tape work inspired by Cage's and Stockhausen's electronic music and a literary technique developed by Burroughs. Adams composed this electroacoustic piece during his time at Harvard University, satisfying the requirement for his master's degree in composition. Unfortunately, by the composer's own admission, he was unaware of how to care for the tape on which the original work was recorded. Over the years the tape completely deteriorated, leading him to claim in his memoir, "Heavy Metal is lost to the ages." ${ }^{5}$ He was mistaken: a single recording of the work exists as part of a larger interview of the composer conducted by Charles Amirkhanian and broadcast on KPFA in Berkeley, California, on April 18, 1973. ${ }^{6}$ 
Adams has explained that his indebtedness to Cage in Heavy Metal stemmed primarily from his exposure to Cage's works of the 1960s, most notably Variations $I V .{ }^{7}$ His citation of this particular work by Cage is odd, given that Heavy Metal is a fixed electroacoustic composition that does not change from performance to performance. Variations $I V$ is, by contrast, a deeply indeterminate work that will differ in each realization. A more likely reason Adams viewed correspondences between Heavy Metal and Variations IV stems from the latter work's being a culmination of Cage's evolving ideas regarding interpenetration and multiplicity. As James Pritchett explains, these two interrelated concepts imagine "an infinite space of sounds that were all unique and completely interconnected: all sounds, in other words, were thought of as existing simultaneously in this space and hence were all interrelated to each other." ${ }^{18}$ In Heavy Metal, Adams crafts just such a sonic environment, with disparate and seemingly unrelated sounds coexisting within the same space. Heavy Metal also suggests influences from Stockhausen, with Adams citing the contemporaneous Telemusik and Hymnen as models. ${ }^{9}$ Both of these works are based on Stockhausen's "moment form," in which time is made vertical and the music avoids functional or conventional implications of continuity and developmental forms. As Jonathan Kramer explains: "A proper moment form will give the impression of starting in the midst of previously unheard music, and it will break off without reaching any structural cadence, as if the music goes on, inaudibly, in some other space or time after the close of the performance."10 The correspondences between Stockhausen's moment form and Cage's concepts of multiplicity and interpenetration describe just as well the chaotic and dissonant sonic environment Adams sought to create, as he included everything from kitchen pots and pans and Beijing opera gongs to radio transmissions. ${ }^{11}$ The particular incorporation of radio transmissions in Heavy Metal suggests a desire to emulate Stockhausen's Hymnen, itself one of his many experiments with moment form, and Cage's pioneering Radio Music. ${ }^{12}$ In addition, the meticulous attention Adams places upon editing and mixing the discrete sound elements in Heavy Metal suggests an awareness of Stockhausen's pioneering interest in musical spatialization. ${ }^{13}$

The experimental literary work of William Burroughs, whose chancebased cut-up technique resulted in a dense prose style that avoids conventional syntax, is also important for understanding how Adams conceived Heavy Metal. In 1970 Burroughs published an essay collection entitled The Electronic Revolution that demonstrates his interest in the possibilities afforded by tape recording and the manipulation of sound. Burroughs viewed the tape recorder as a technology with the potential to subvert language and the limits it places upon human understanding. ${ }^{14} \mathrm{He}$ envisioned a hypothetical pop festival that would involve a 
vast grid of tape recorders placed everywhere to envelop audiences and demonstrate the best application of the cut-up technique for entertainment purposes. ${ }^{15}$ On a more general level, Burroughs's ideas about tape recorders and sound were part of a larger wave of ongoing experimentation with previously unconsidered dimensions of the medium, with tape loops, samples, and feedback becoming sources of creative invention; Steve Reich's Come Out and It's Gonna Rain stand as particularly conspicuous and relevant examples. ${ }^{16}$ Douglas Kahn, when surveying the ideas espoused in Burroughs's philosophical writings, suggests that "among the postwar arts only Cage was on par with Burroughs in the sophistication of his ideas about sound."17

When discussing Heavy Metal in 1973, Adams stated that the piece's text drew exclusively from the last paragraph of Burroughs's 1961 novel The Soft Machine..$^{18}$ Adams was mistaken in this regard, as the opening of Heavy Metal uses a textual fragment from Naked Lunch, a text not devised through the cut-up technique: "And I would like to remind you, Gentlemen and Hermaphrodites of the Jury, that this Great Beast ... has appeared in this court on many previous occasions, charged with the unspeakable crime of brain rape. ... In plain English. In plain English, Gentlemen, forcible lobotomy." ${ }^{19}$ Where Adams casually drew on ideas from Cage and Stockhausen when composing Heavy Metal, he followed the same process when he chose the texts. Their general mood and atmosphere was the most appealing aspect, not the technical aspects of the cut-up technique. Adams confirmed this sentiment during the 1973 interview, indicating an awareness of Burroughs's experiments with recording his voice with tape recorders: "[Heavy Metal] is a reaction, on my part, to Burroughs' prose, his rhythm, his use of words, and also to his own style of reading. I really went through a heavy Burroughs period. I was very interested in his technique of cutting up and pasting back, which is a technique where he writes a conventional page of prose and then, in a kind of Cagean style, cuts it up, and kind of randomly reassembles it ... and then sort of makes a compilation of that." ${ }^{20}$ Adams's conflation of Cage and Burroughs is significant, indicating a loose understanding of their similarities and differences. The cut-up technique Burroughs devised had aesthetic aims different from the indeterminacy and chance procedures of Cage. Burroughs was preoccupied with examining human subjectivity, which he viewed as "internalized, intersubjective discourses which are in turn (mis)recognized as individual." The cut-up technique and the resulting reconfigured text allowed Burroughs to subvert what he called the "Reality Script," or entrenched systems of signification. ${ }^{21}$ The indeterminacy used by both Cage and Burroughs, while different, shares a focus on exploring human subjectivity and placing the reader or listener in a fundamentally new position of associative and interpretive possibilities. ${ }^{22}$

The ominous atmosphere and science fiction tropes and jargon that permeate both Naked Lunch and The Soft Machine resemble the type of 
tenebrous and anarchic sound world Adams crafted in Heavy Metal through his exposure to Cage, Stockhausen, and Burroughs. ${ }^{23}$ Aside from the introduction, which draws from the aforementioned passage from Naked Lunch, Heavy Metal consists entirely of staggered and fragmented repetitions from the final paragraph of The Soft Machine. The text is recited, not sung, fitting with the shifts of blurry and fragmented imagery demarcated by Burroughs's ubiquitous em dashes:

Think Police keep all Board Room Reports-and we are not allowed to proffer the Disaster Accounts-Wind hand caught in the door-Explosive Bio-Advance Men out of space to employ Electrician in gasoline crack of history-Last of the gallant heroes- ' $\mathrm{I}$ ' $\mathrm{m}$ you on tracks, Mr. Bradly Mr. Martin" —Couldn't reach flesh in his switch-and zero time to the sick tracks-A long time between suns I held the stale overcoat-sliding between light and shadowmuttering in the dogs of unfamiliar score-cross the wounded galaxies we intersect, poison of dead sun in your brain slowly fading-Migrants of ape in gasoline crack of history, explosive bio-advance out of space to neon-“'I'm you, Wind Hand caught in the door"-Couldn't reach flesh-In sun I held the stale overcoat, Dead Hand stretching the throat-Last to proffer the disaster account on tracks. "See Mr. Bradly Mr.-"And being blind may not refuse to hear: "Mr. Bradly Mr. Martin, disaster to my blood whom I created." 24

Despite the opaque language, subtle repetitions of short words and phrases make the above passage well suited as the textual basis for an avant-garde electronic work. For example, the following words occur multiple times: "Mr. Bradly," "Mr. Martin," "gasoline crack of history," "disaster," and "Explosive Bio-Advance." These words and their distorted iterations in Heavy Metal provide the work an intuitive sense of repetition, a fact corroborated by the work's form (table 1). There are three extended iterations of portions of the final paragraph from The Soft Machine, punctuated by transitional passages without the voice, and an introduction provided by the fragment from Naked Lunch.

While Adams was aware of avant-garde principles and aesthetics and their realization in influential works, he used this awareness to craft a sound world in Heavy Metal that is conventional, even predictable. The chaotic mood he creates serves to aurally illustrate the prose's imagery in a manner similar to Milton Babbitt's earlier use of electronics in his evocative and dramatically potent Philomel (1964), despite the differences in compositional methods behind the works. Indeed, in a 1983 interview, Adams described Heavy Metal as "a very violent piece, very strongly affected by the ambiance of those novels. There's a lot of explosions and chaotic sorts of Holocaust-type levels in it." ${ }^{25}$ Apocalyptic overtones similarly factored into Reich's repetition 
Table 1. Formal layout of Heavy Metal.

\begin{tabular}{ll}
\hline Section & Burroughs text \\
\hline 0:00-1:17- & And I would like to remind you, Gentlemen and Hermaph- \\
Introduction (from & rodites of the Jury, that this Great Beast . . . has appeared \\
Naked Lunch) & in this court on many previous occasions, charged with the \\
& unspeakable crime of brain rape. ... In plain English. In plain \\
& English, Gentlemen, forcible lobotomy.
\end{tabular}

1:18-1:54-Transition

1:55-3:09-Section I (from The Soft Machine)

Mr. Bradly Mr. Martin, disaster to my blood whom I created-Dead Hand stretching the throat-Last to proffer the disaster account on tracks. "See Mr. Bradly Mr.-" And being blind may not refuse to hear: "Mr. Bradly Mr. Martin, disaster to my blood whom I created"

3:10-7:35-Transition

7:36-9:41-Section II (from The Soft Machine)

Wind hand caught in the door-Explosive Bio-Advance Men out of space to employ Electrician in gasoline crack of history-Last of the gallant heroes- "I'm you on tracks, Mr. Bradly Mr. Martin"-Couldn't reach flesh in his switch-and zero time to the sick tracks-A long time between suns I held the stale overcoat-sliding between light and shadow-muttering in the dogs of unfamiliar score-cross the wounded galaxies we intersect, poison of dead sun in your brain slowly fading-Migrants of ape in gasoline crack of history, explosive bio-advance out of space to neon-“I'm you, Wind Hand caught in the door"-Couldn't reach flesh-In sun I held the stale overcoat, Dead Hand stretching the throat-Last to proffer the disaster account on tracks. "See Mr. Bradly Mr.-" And being blind may not refuse to hear: "Mr. Bradly Mr. Martin, disaster to my blood whom I created"-Last to proffer the disaster account on tracks. "See Mr. Bradly Mr.-"

9:42-11:54-Transition

11:55-13:04-Section III (from The Soft Machine)

Think Police keep all Board Room Reports-and we are not allowed to proffer the Disaster Accounts-Wind hand caught in the door-Explosive Bio-Advance Men out of space to employ Electrician in gasoline crack of history-Last of the gallant heroes- "I'm you on tracks, Mr. Bradly Mr. Martin"Couldn't reach flesh in his switch-and zero time to the sick tracks-A long time between suns I held the stale overcoatsliding between light and shadow-muttering in the dogs of unfamiliar score-cross the wounded galaxies we intersect, poison of dead sun in your brain slowly fading

13:05-13:45-Closing

of spoken words on tape in It's Gonna Rain. The text found in the majority of Heavy Metal suggests Adams had an instinct for utilizing material with nonsystematic repetition. This interest takes on a more explicitly minimalist orientation in his first professional commission: Hockey Seen. 


\section{"Hockey Seen" (1972)}

No other work of Adams's juvenilia better exemplifies his youthful attempts to synthesize disparate musical conventions than the forty minutes of electronic music he composed for Nelson Goodman's 1972 multimedia project Hockey Seen: A Nightmare in Three Periods and Sudden Death. To understand how Adams produced this large work, we first need to understand the commissioning organization.

The Graduate School of Education at Harvard University established Project Zero in 1967 as an extension of the philosopher Nelson Goodman's work on a general theory of symbols. ${ }^{26}$ Project Zero was well established enough by 1972 to offer commissions to artists who could contribute to their educational goals. Adams was one such beneficiary. In the summer of 1972, he received funding to compose an "electronic score" for Goodman's multimedia project Hockey Seen. ${ }^{27}$ Adams must have completed the work quickly, spending approximately seven weeks composing the score on the ARP synthesizer at Brandeis University before the premiere in August. ${ }^{28}$ Speaking in 1983, Adams described the overall effect of the theatrical collaboration as a "kind of terpsichorean tragedy." ${ }^{29}$ From Goodman's perspective, Hockey Seen was an opportunity to put his philosophical ideas, most notably the idea of "worldmaking," into practice. He felt that both science and art offered means to comprehend the "worlds" we create around us. As he stated in Ways of Worldmaking, "The arts must be taken no less seriously than the sciences as modes of discovery, creation, and enlargement of knowledge in the broad sense of advancement of the understanding, and thus that the philosophy of art should be conceived as an integral part of metaphysics and epistemology." ${ }^{130}$ Evidence indicates that Adams held little understanding of Goodman's philosophical ideas while composing the music for Hockey Seen in 1972. When describing the project in 1983, the composer only remembered that he was commissioned by "a highly respected philosopher whose name is Nelson Goodman, who's written many books on the philosophy of art. I wouldn't know what field, whether he's phenomenology or what. He's a professor at Harvard, and he's always writing articles in which he's disputing Noam Chomsky or vice versa. He's definitely a blue-ribbon philosopher and psychologist." ${ }^{31}$ Adams's primary goal while composing Hockey Seen was to illustrate musically what he described as hockey's primary features: "a certain profuseness of violence and intense activity." ${ }^{\prime 2}$

"Period One," the longest movement of Hockey Seen, begins with a six-minute drone outlining the first four pitches of an overtone series on C-sharp (example 1). This static musical texture accompanies an austere slide projection alongside the choreography. Such an introduction may suggest that Adams had some awareness of contemporaneous dronebased minimalism. A piercing referee whistle interrupts this drone after 
Example 1. John Adams, Hockey Seen, "Period One" drone. Transcription of audio material. Bequest from the Estate of Nelson Goodman. Property of the Haggerty Museum of Art, Marquette University (2000.18).

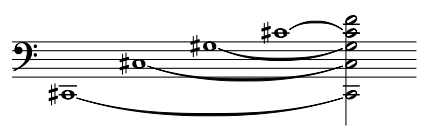

six minutes, creating a structural break that generates greater musical activity. The primary thematic material for "Period One" is an unusual passacaglia theme, which Adams referenced when discussing the work with Amirkhanian on KPFA in 1973 (example 2). ${ }^{33}$ Above and preceding this passacaglia theme is a motoric accompaniment of simple tertian harmonies (example 3).

This texture and the distinctive synthesizer timbre also share superficial correspondences with the Who's "Baba O'Riley," whose introductory passage was influenced by the minimalist composer Terry Riley. The song was released on the album Who's Next in August 1971, immediately before Adams began work on Hockey Seen. ${ }^{34}$ Adams has remarked on his exposure to such popular music and the valuable pedagogical function it provided:

Back in the dorm room and at all-night parties of pot, scotch, whiskey, and unfiltered Lucky Strikes, we bored like weevils through the harmonic changes and textual minutiae of albums by the Paul Butterfield Blues Band, Rahsaan Roland Kirk, Bob Dylan, Cream,

Example 2. John Adams, Hockey Seen, "Period One" passacaglia theme. Transcription of audio material. Bequest from the Estate of Nelson Goodman. Property of the Haggerty Museum of Art, Marquette University (2000.18).

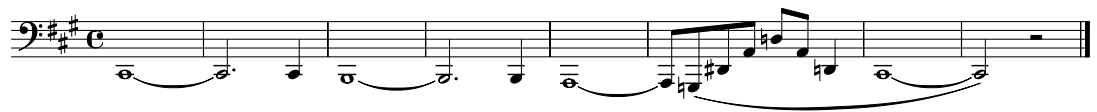

Example 3. John Adams, Hockey Seen, "Period One" passacaglia theme accompaniment. Transcription of audio material. Bequest from the Estate of Nelson Goodman. Property of the Haggerty Museum of Art, Marquette University (2000.18).

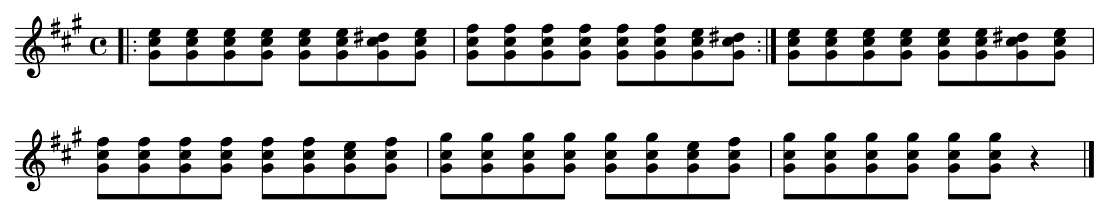


Jefferson Airplane, The Electric Flag, Country Joe and the Fish, the Beach Boys, the Doors, and of course, Jimi Hendrix.... I made more progress in my command of harmonic practice by reproducing these pop songs from memory at the piano than I ever did by my forced marches through the figured bass treatises. ${ }^{35}$

Like the passage in Hockey Seen, "Baba O'Riley" begins with an active surface outlining simple triadic harmonies with the eventual arrival of a repetitive bass motive (example 4). Adams, by contrast, builds his accompaniment upon block chords. Without reading too much into putative or superficial similarities with "Baba O'Riley" specifically, we can discern that Adams composed Hockey Seen with popular music conventions on his mind as a means to cultivate audience appeal: "It's sort of a piece of pop music in a way. I realized that my audience wasn't going to be the type of audience that would come to, say, a new music ensemble concert." 36

"Period One" uses the passacaglia theme as a loose means to create a theme-and-variations form. Instead of drawing on the original passacaglia theme in the final minutes, however, Adams created a new serpentine chromatic descent (example 5) based on discrete pitches, pairing it with a harsh upward ascent in the synthesizer's upper register in which frequencies are elided into a smooth upward continuum; the result is a vertigo-like effect of aural disorientation. After this passage breaks off, Adams composed a final détente: a sustained bass pedal on G-sharp with an arpeggiation of the pitches B, A, and G-sharp, again suggesting a faint similarity to the iconic "Baba O'Riley" opening (example 6).

Example 4. "Baba O'Riley" introduction surface reduction.

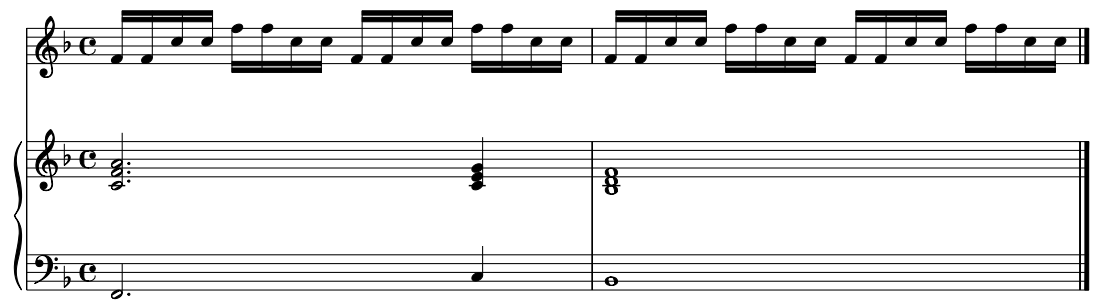

Example 5. John Adams, new passacaglia theme in Hockey Seen, "Period One" (conclusion). Transcription of audio material. Bequest from the Estate of Nelson Goodman. Property of the Haggerty Museum of Art, Marquette University (2000.18).

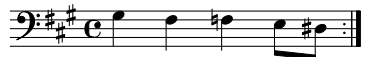


Example 6. John Adams, Hockey Seen, "Period One" final texture. Transcription of audio material. Bequest from the Estate of Nelson Goodman. Property of the Haggerty Museum of Art, Marquette University (2000.18).

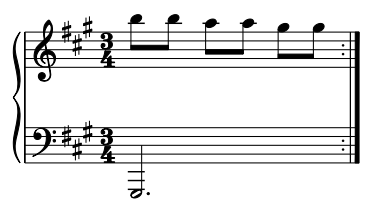

Subsequent periods of Hockey Seen indicate other influences as Adams sought to convey the sport's kinetic energy and activity. For example, "Period Two" begins with a percussive thematic motive (example 7) that suggests the game's violent impacts in a manner reminiscent of Stravinsky's Rite of Spring. Adams imbued his opening motive with an aggressive quality through a repetitive and dissonant play on registral displacement between the upper and lower voices. Also significant in this period is Adams's use of musique concrète elements, specifically, crowd noises and the sound of a hockey puck skipping across ice. Adams subjects such "found sounds" to meticulous spatialization, perhaps suggesting correspondences to Heavy Metal and the Stockhausen interests that inspired it-and brings them back periodically to create a repetitive musical continuity. "Period Three" again involves drones as a foundational background to the choreography. Unlike in "Period One," however,

Example 7. John Adams, Hockey Seen, "Period Two" opening theme. Transcription of audio material. Bequest from the Estate of Nelson Goodman. Property of the Haggerty Museum of Art, Marquette University (2000.18).
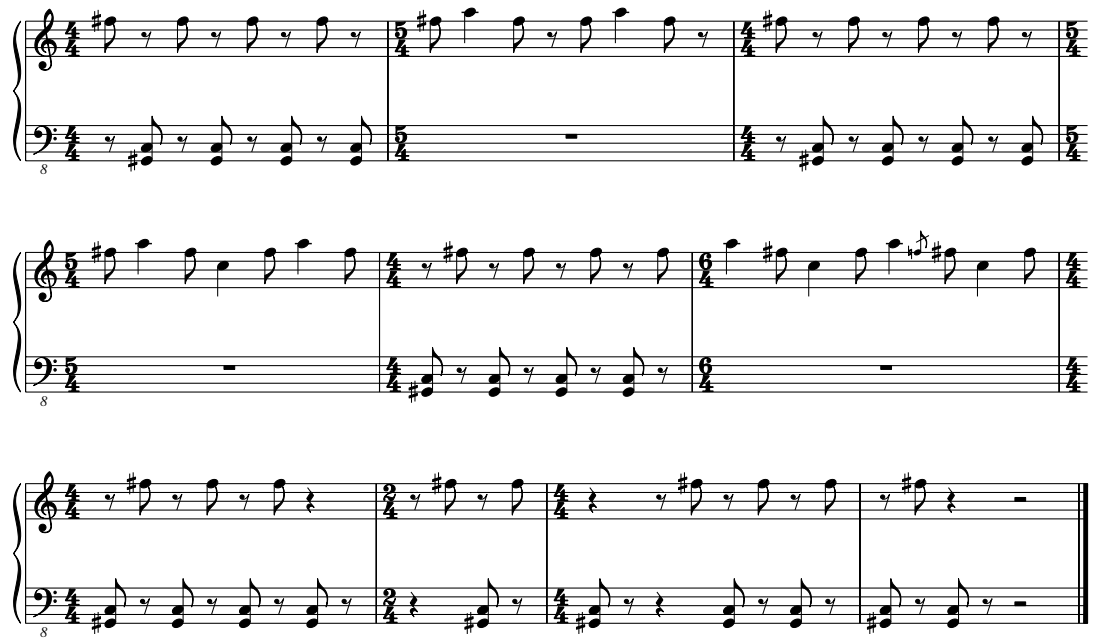
the drone never ceases, serving as the harmonic foundation for the entire period. Adams also favors a drone that is far harsher than the one we find in "Period One," which relies upon consonance through the first pitches of the overtone series. The chord Adams chooses for "Period Three" is a B diminished seventh, a dissonant sonority providing the foundation for a dense web of short, pointillistic gestures subjected to electronic distortion effects to obscure easy pitch identification.

"Sudden Death" is the final period of Hockey Seen and also the briefest. In it Adams created a series of short, simple, and repeatable thematic motives that he could subject to sudden and unprepared timbral and harmonic shifts. The overall effect of "Sudden Death," like "Period Two," is one of aesthetic confusion. Adams fused several disparate musical ideas together into a composite that is irregular in overall architecture and aesthetically baffling. Although clumsy in execution, Hockey Seen was a valuable work in demonstrating to Adams the exciting possibilities of synthesizing various avant-garde influences.

Surprisingly, Hockey Seen met with critical success when it premiered. ${ }^{37}$ Even in the late 1970s, when Adams had already moved to the Bay Area and begun establishing himself as a minimalist/postminimalist composer, he still viewed the music positively. As an August 1979 letter to Goodman demonstrates, Adams found that "the music still seems well suited to the tone of the production" and that Hockey Seen carried with it "an undeniable cleverness and energy." Farther along in the letter however, Adams voiced some reservations, finding that Hockey Seen was too long to sustain the drama the collaborators sought. He singled out "Period One" as the weakest: "The music seems pompous and smacking of Hollywood. . . I would not miss it if the whole of Period I were deleted (after the drone and opening whistle). ${ }^{\prime 38}$ Despite this selfcriticism, Adams found the other periods compelling.

Only four years later, however, Adams was far more critical. As he explained, "It was just a desperately corny and embarrassing production, to which I contributed a great deal of desperately corny synthesizer music. I have no interest in hearing that on my seventy-fifth birthday!"39 What explains such a stark reversal? Part of Adams's embarrassment about Hockey Seen could have stemmed from the overall sound quality. Hockey Seen would not have sounded "corny" in 1972, as many composers experimented with cutting-edge synthesizers like the ARP, which the young Adams was also using. ${ }^{40}$ By the time of his reversal in the early 1980s, however, the synthetic timbres in Hockey Seen were widely associated with commercialized synth-pop music; the avant-garde had lost the exclusive claim to that sound quality they had enjoyed in the decade prior. ${ }^{41}$ In addition, Adams had received serious critical acclaim beginning in the early 1980s with his large-scale choral symphony, Harmonium (1981), and created a succès de scandale at the East Coast premiere of 
Grand Pianola Music in June 1982 at Avery Fisher Hall. ${ }^{42}$ Having established himself by 1983 as a major composer working within the minimalist and postminimalist styles and drawing on conventional orchestral and instrumental forces, perhaps Adams would have preferred to forget a work like Hockey Seen.

$$
\text { "Ktaadn" (1972-74) }
$$

Hockey Seen suggests that Adams's engagement with tonality and modality and his awareness of gestures and conventions of musical minimalism began well before 1977, the year of his self-described "opus one." The work that best reflects Adams's interest in minimalism is his choral piece, Ktaadn (1972-74). This was Adams's first thoroughly indeterminate composition, drawing from both Cage's methods and his love for Henry David Thoreau. Several of Cage's works reflect his attraction to Thoreau, one of which, Mureau, Adams saw and heard in concert in 1971: "The tables and chairs had been cleared and the audience was clustered around on the floor, listening to Cage, who was seated at a table with nothing more than a typed manuscript, a microphone, and a reading lamp. His reading was from a long piece called Mureau, made by submitting passages from Thoreau's journals to chance procedures via the I Ching." ${ }^{\prime 3}$ The passages Cage selected from Thoreau's journal for use within Mureau derived from references the author made to music, silence, and sounds of the natural environment. Adams, a native New Englander, would likely have felt a special interest in Mureau and Thoreau. Also significant for Adams when composing Ktaadn was the environmental dimension of Cage's aesthetics in the 1960s and 1970s, which drew from the influence of Thoreau. ${ }^{44}$ The most pronounced intersection between Adams and Thoreau, offering a strong link to the creative genesis of Ktaadn, comes from the 1970 publication and premiere of Cage's Song Books.

There is a striking correspondence between the score for Ktaadn and one of the songs from Cage's Song Books. The instructions for this songSolo for Voice 3 from volume 1 of the set-require the performer to consult a map of Concord, Massachusetts, provided by Cage (example 8). Performers trace a path from one point on the map, Fair Haven Hill (H7), to the other, "the house beyond Blood's" (B8), by making their own decisions and turning the map so the selected path suggests a melodic line. The performer is free to set on this melodic line any of the text Cage includes on the score's subsequent pages; the text is culled from Thoreau's journal. ${ }^{45}$ With Adams's Ktaadn, we observe a similar use of a map as a source of compositional invention. Inspired by Thoreau's description of climbing Mount Katahdin in his book The Maine Woods, Adams obtained a map of the mountain that included the names of various Abenaki villages and bodies of water in the vicinity. ${ }^{46} \mathrm{He}$ then drew a fifty-mile radius around the mountain's peak, basing his choice on the 
Example 8. Map of Concord, Massachusetts, from John Cage, Song Books, vol. 3 (New York: C. F. Peters, 1970). Copyright (c) 1970 by Henmar Press, Inc. Used by permission of C. F. Peters Corporation. All rights reserved.

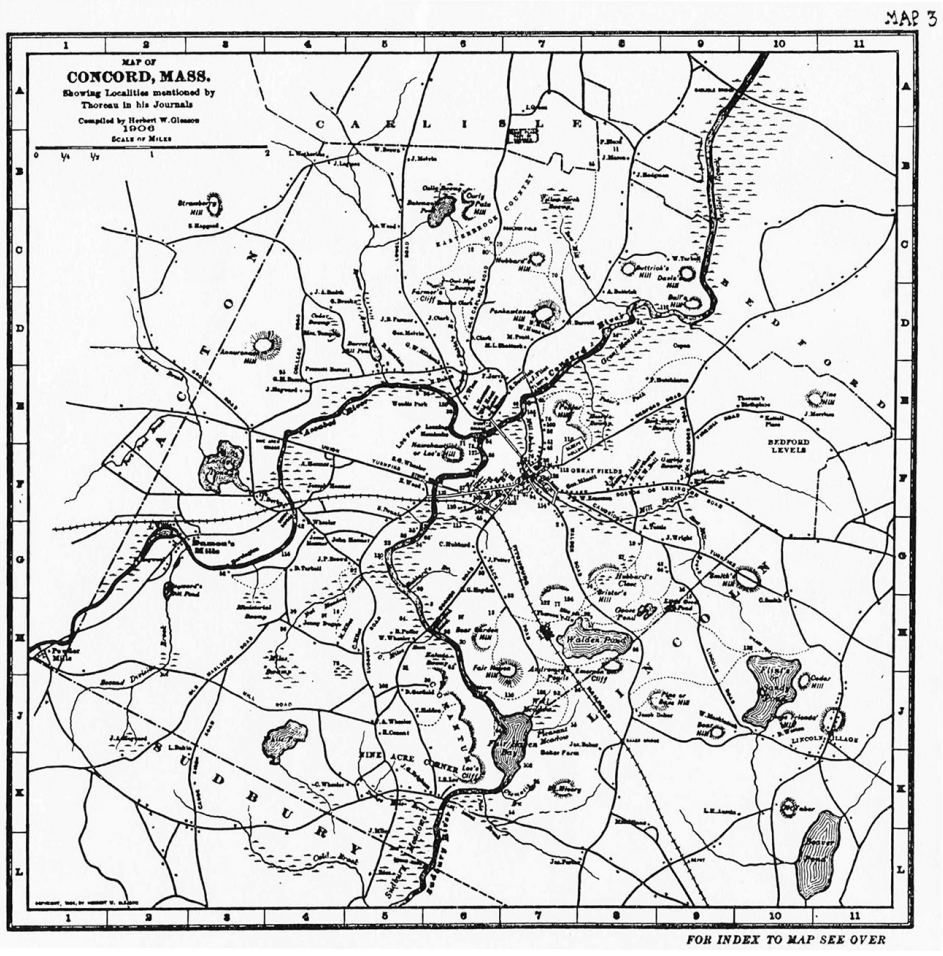

distance he imagined Thoreau might have been able to see on a clear day. Next, he set each Abenaki name contained within the circle to a short modal melody and a nonpitched rhythmic cell. Adams composed all of the modal melodies in such a way that the entire work utilizes only the pitches between $\mathrm{D}$ and $\mathrm{A} .^{47}$

The vocal forces for Ktaadn are divided into two groups: singers and nonpitched speakers. Whereas the singers perform the aforementioned modal melodies set to Abenaki words, the speakers, each of whom is paired with a singer to create a duo, recite the same Abenaki words as their partners but in unrelated and uncoordinated rhythmic patterns and meters. Each Abenaki word is given a discrete module with repeat signs, facilitating the repetition required in performance. Such score design suggests awareness of Riley's notational scheme for In C (1964) and related works. The words themselves are laid out in alphabetical order, and the performing pairs may determine the order of the modules' performance using various strategies, a few of which Adams suggests in his performance notes. Possibilities include rhythmic ordering, with words organized according to stresses or other rhythmic peculiarities; phonetic 
ordering, with words organized according to conspicuous vowel or consonant sounds; and syllabic ordering, with words organized according to the number of syllables in a word (shortest progressing to longest, or vice versa). ${ }^{48}$

What is most striking about Ktaadn is that it falls into the D Lydian mode between the pitches $\mathrm{D}$ and $\mathrm{A}$, which Adams indicates with a key signature featuring F-sharp and G-sharp (example 9) ${ }^{49}$ The use of such limited modal pitch collections in a modular notational format points to a tension for Adams with complete indeterminacy in performance. The rhythms and pitches are fixed, and a tempo for the work is prescribed, as is a requirement for accompanimental periodic sounds or drones. ${ }^{50}$ Due to the wide-ranging number of syllables in a given word, diverse rhythmic and melodic combinations arise. Sometimes a word with many syllables will be repeated only once or twice, as we observe with the word "Abacotnetic" (example 10). The corresponding speaker module is also short and consists of only a single statement of the word (example 11). A different configuration is exemplified by the word "Allagash" (example 12). Here, the constituent syllables are broken up, gradually accumulating across the module toward complete enunciations of the word at the end, a feature not found within the corresponding speaker module, which is far shorter (example 13).

Using this framework to examine every Abenaki word found in Ktaadn yields three categories: either a simple or a complex treatment of the words and a third, intermediary class (table 2). "Simple" here designates

Example 9. John Adams, Ktaadn Lydian pitch content.

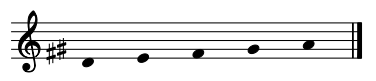

Example 10. John Adams, Ktaadn, "Abacotnetic" singer module. Transcription of Ktaadn manuscript in the John Adams Papers, San Francisco Conservatory of Music Archives, San Francisco, CA.

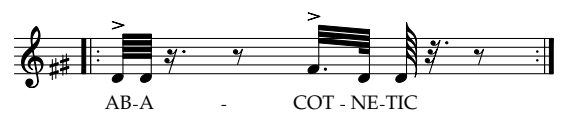

Example 11. John Adams, Ktaadn, "Abacotnetic" speaker module. Transcription of Ktaadn manuscript in the John Adams Papers, San Francisco Conservatory of Music Archives, San Francisco, CA.

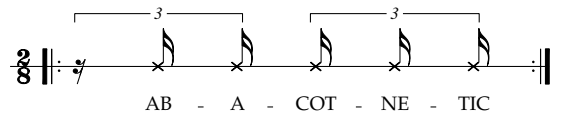


Example 12. John Adams, Ktaadn, "Allagash" singer module. Transcription of Ktaadn manuscript in the John Adams Papers, San Francisco Conservatory of Music Archives, San Francisco, CA.
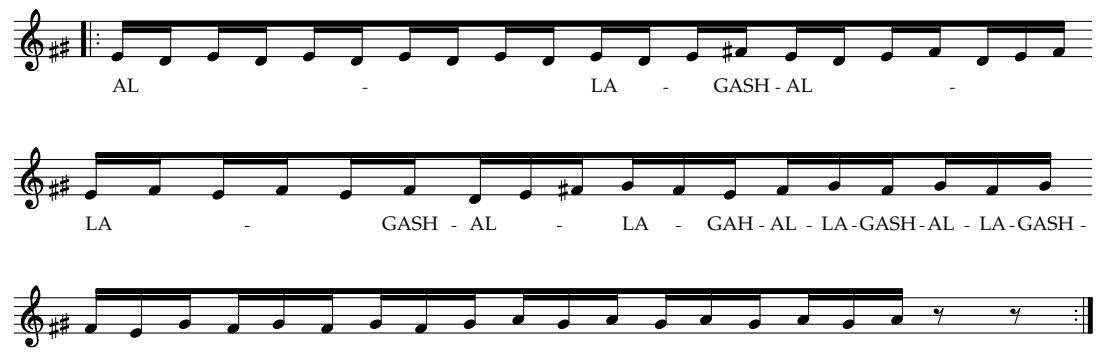

AL - LA GASH AL - LA GASH AL - LA GASH AL - LA GASH AL - LA GASH AL - LA GASH

Example 13. John Adams, Ktaadn, "Allagash" speaker module. Transcription of Ktaadn manuscript in the John Adams Papers, San Francisco Conservatory of Music Archives, San Francisco, CA.

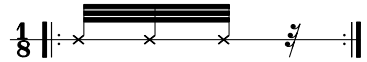

AL - LA - GASH

Table 2. Diagram of Abenaki words in Ktaadn.

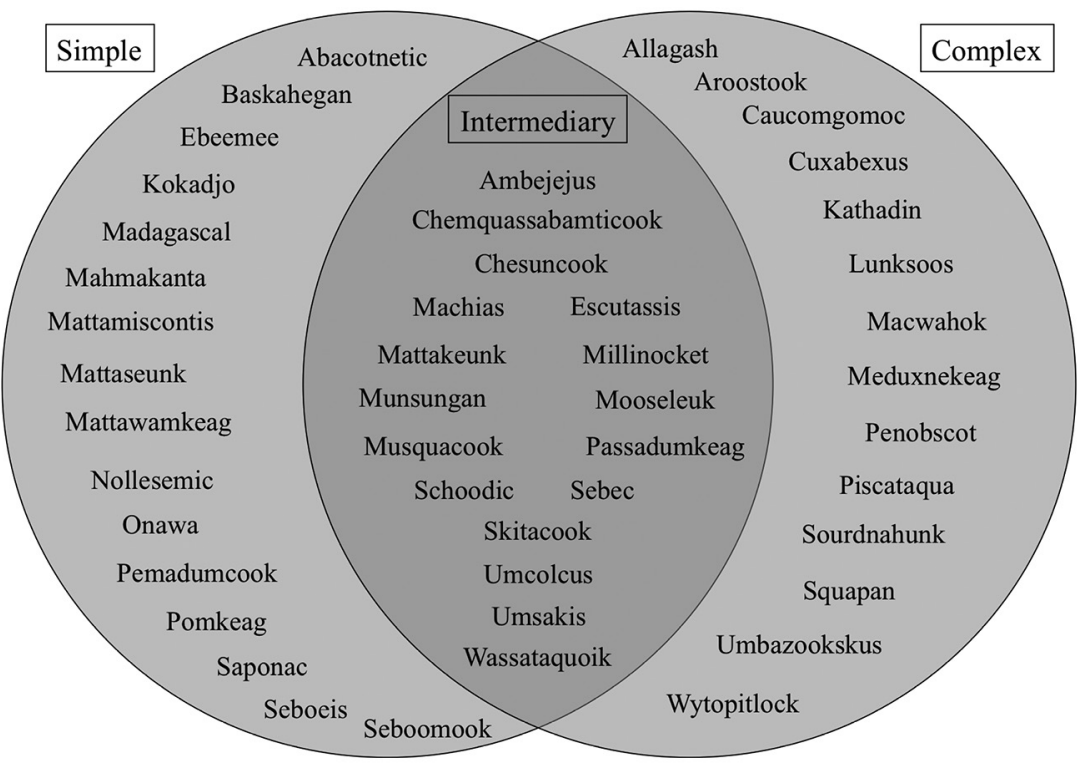


a module tending to be shorter and with little, if any, syllabic distortion. "Complex" modules feature far greater length, fragmentation, and intricate designs that can become quite elaborate. This distinction between simple and complex only matters for the singers, as all speaker modules consist of a single enunciation of an Abenaki word.

There is strong evidence that Cage's and Thoreau's interests in environmentalism influenced Adams while he was writing Ktaadn. The unpublished manuscript of Ktaadn includes a short epigraph on the score's first page: "I will never forget the thrill I received the day I met the officials of the Great Northern Paper Company and received from them the deed to the mountain I had purchased. It had taken me twenty-eight years to obtain the first 6,000 acres on the mountain, but it was worth it." 51 These are Percival Proctor Baxter's words, printed in the Bangor Daily News on May 3, 1938. After his tenure as the governor of Maine from 1921 to 1925, Baxter dedicated the next three decades of his life to protecting Mount Katahdin and the surrounding wilderness, using a great deal of his own personal wealth to acquire over two hundred thousand acres, which he subsequently deeded to the state. That land became Baxter State Park, established in 1933. It was dedicated to the cause of conservation, eschewing roads, electricity, and other modern amenities, in keeping with Baxter's desire to maintain the land in a state that was "forever wild." ${ }^{52}$ This epigraph reflects Adams's awareness of the history surrounding Mount Katahdin and Baxter State Park. The composer felt a personal connection to this locale that transcended an abstract desire to compose a work that simply appropriated Abenaki words within the mountain's vicinity, suggesting that environmentalism and conservation were an underlying stimulus for the work. Cage's contemporaneous environmentalism, drawn from Thoreau, and the broader pushes for progress in environmental legislation and conservation efforts in the 1970s all had a likely influence on the writing of Ktaadn.

At the work's premiere, Ktaadn pushed audiences to the brink with boredom, leading to Adams's disenchantment with the work. While pairing consonance and modality with indeterminacy in a manner similar to Riley and other minimalists may have provided a more listener-friendly sonic result, other problems became apparent. Due to the indeterminate performance time, for example, Adams recalled, "the result was a congenial but resolutely uneventful chaos of communal mumbling. I was hard put not to acknowledge the tedium that set in at about the fifth minute-once the audience realized that things were unlikely to change." ${ }^{53}$ Indeed, just such a complaint arose in George Kauffman's review in the Berkeley Barb of the Ktaadn premiere in May 1974: "While it was a bit too long, the ending was magnificent." ${ }^{54}$ Although Ktaadn was less confused, clumsy, and derivative in terms of its compositional integrity than works such as Heavy Metal and Hockey Seen, Adams still 
ran into problems in the realization and execution of his indeterminate piece. Despite the young artist's move toward greater originality, the sonic result still turned out to be less than satisfying.

\section{"Christian Zeal and Activity" from "American Standard" (1972-73)}

Some readers may be familiar with "Christian Zeal and Activity," a stand-alone and relatively conventional work for chamber orchestra and tape that Adams includes in his current list of compositions available for performance. The original form of "Christian Zeal and Activity" as conceived in 1973, however, was a single movement within a larger work entitled American Standard that involved experiments with notation and the aesthetic possibilities of incorporating political messages into music. Each movement of American Standard explores a single compositional parameter while borrowing from topics and styles from well-known American vernacular musical traditions of past eras. As Adams explained in 1973, the first movement, entitled "John Philip Sousa," explores rhythmic construction, drawing upon traditional march gestures. The third movement, "Sentimentals," explores the relationship between melody and harmony by reworking Duke Ellington's "Sophisticated Lady." Adams dedicates the second movement, "Christian Zeal and Activity," to the compositional parameter of voice leading. In this movement, he takes Arthur Sullivan's hymn "Onward, Christian Soldiers" and displaces or staggers the anticipated voice leading, overlaying the music with a radio broadcast concerning religious fundamentalism. ${ }^{55}$

Throughout American Standard, one can detect the influence of Cornelius Cardew, Christian Wolff, and other politically engaged composers of the 1970s. The 1970s also saw Charles Ives achieve greater coverage and status as a canonical composer for his exemplification of American individualism and self-expression. Doubtless the young Adams was aware of Ives and the model his experimentation with polystylistic layerings of American vernacular material could provide. ${ }^{56}$ While Adams was a strong partisan for Cage's ideals at this time, he also voiced an interest in Cardew's work with the experimental Scratch Orchestra in England. Adams guided the rehearsals of the San Francisco Conservatory New Music Ensemble in the egalitarian spirit of Cardew, and he wore his politics on his sleeve:

The first thing I'm doing is trying to lower my profile as "director," "conductor," "changer de faire" and so on and so forth. I'm beginning to find conducting a sort of swinish occupation and I try to do as little of it as possible. What I do is I play. I just consider myself 
one of the group and we try to operate in the chamber music tradition. ... The second thing I'm trying to do is to relegate a lot of the decision making process, which you come across in any new piece of music, to a kind of democratic council. ${ }^{57}$

Adams's egalitarianism extended to the instructions he attached to his scores of the era. The LP liner notes that accompanied the recording of American Standard, released under Brian Eno's Obscure Records label in 1975, specifically resemble those for Wolff's Burdocks (1970-71). Wolff indicates that an ensemble performing Burdocks should "gather and decide" or select "one or more representatives to decide" which sections of the composition to play and in what order..$^{58}$ Adams echoed this directive in American Standard, stating that any ensemble problems are "to be worked out in standard American fashion: proposal, debate and vote." ${ }^{159}$ Adams may have also been drawn to Wolff's ongoing interest in deconstructing and rearranging vernacular music, particularly worker songs and political tunes, in the 1970s. In Wobbly Music (1975-76), for example, Wolff sought to connect the musical and political, drawing on three workers songs to craft a work extolling a collective social consciousness. ${ }^{60}$ Earlier pieces such as Accompaniments (1972) and Changing the System (1973-74) also fall into this political period of composition for Wolff as he sought to represent a "kind of revolutionary noise." ${ }^{61}$ There is little evidence of Adams inscribing in American Standard a similarly explicit and partisan political subtext. He does, however, focus on collective performance, indeterminacy, and borrowing extensive passages from vernacular musical traditions and subjecting them to rearrangement.

In a manner similar to Ktaadn, "Christian Zeal and Activity," the second movement of American Standard, relies on a modular scoring format to control the musical continuity. The instructions specify that the ensemble should divide itself into four groups based on instrumental range, with each group containing at least one instrument with long sustaining capacities. Within each of these four groups, a designated leader provides cues to determine when the musicians move from one pitch to another. The score for "Christian Zeal and Activity" consists of four notated staves without bar lines or time signatures that are grouped into five large modules that take up two pages (almost like systems in conventional notation). Within a given module, Adams sometimes uses long stems to connect notes meant to sound simultaneously among the groups (example 14). The effect is an indistinct or hazy alignment between the individual musical parts, with occasional points of unity. The visual quality of the notational scheme Adams uses, in which indeterminacy is mixed with fixed points of coordination, suggests correspondences to Morton Feldman's similar experiments in the 1960s, with solid vertical lines indicating sounds meant to occur at the same time. ${ }^{62}$ The resulting 
Example 14. John Adams, "Christian Zeal and Activity," excerpt from module one.

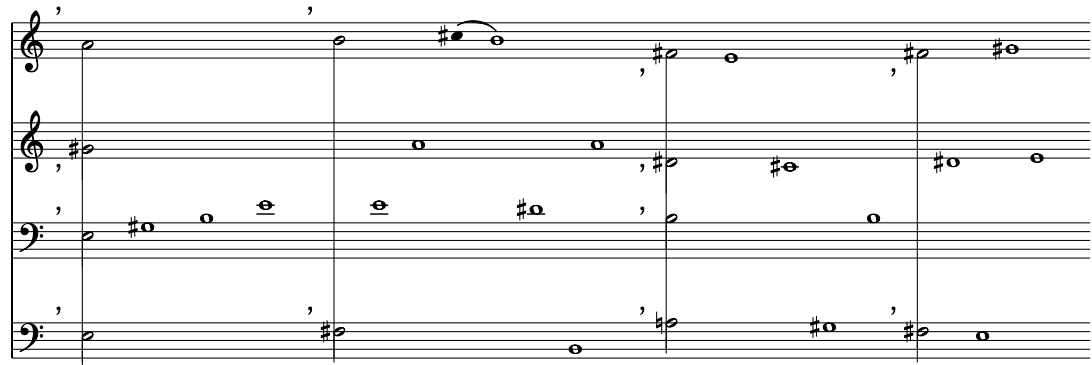

sonic effect of "Christian Zeal and Activity" is similar to these kinds of Feldman scores, with the amoeba-like quality of Adams's musical continuity pushed and pulled by the dialogue between unity and indeterminacy. The overall form of "Christian Zeal and Activity" takes on a vaguely arch-like quality, with the greatest amount of indeterminacy occurring in the fourth module (example 15). The fourth module contains only a single long stem, leaving the bass instruments in the lowest module to oscillate freely while the other pitches float above.

Perhaps the greatest influence on "Christian Zeal and Activity" was Gavin Bryars, the British minimalist who composed Jesus' Blood Never Failed Me Yet in 1971 for tape and ensemble. As early as March 1974, Adams's close contact with Bryars resulted in the San Francisco Conservatory New Music Ensemble performing an entire concert of English experimental music, including an original commission from Cardew. ${ }^{63}$ Adams invited Bryars to conduct this concert and included Jesus' Blood Never Failed Me Yet on the program. ${ }^{64}$ Bryars's work is clouded in moral ambiguity, in Cecilia Sun's examination. On the one hand, "Bryars' accompaniment for the old man's tune-complete with gloriously clichéd suspensions and a consequent phrase that opens with a hackneyed descending-fifth sequence of altered dominants-is surely a perfect example of sentimentality." On the other hand, Bryars subjects this sentimentality of the source material to tape looping that can come across as cold, mechanical, or clinical. ${ }^{65}$ "Christian Zeal and Activity" uses a scheme similar to Jesus' Blood Never Failed Me Yet, pairing an accessible and unobtrusive instrumental texture with a "found sound" element (the prerecorded tape part) based in religious subject matter. The crucial difference between these two works is that Adams takes an explicitly ironic approach when handling his found sound material by pairing it with another person's music. Rather than composing original music and using the found sound material in a manner that could be read as sincere, Adams pairs his deconstruction of Sullivan's hymn "Onward, 


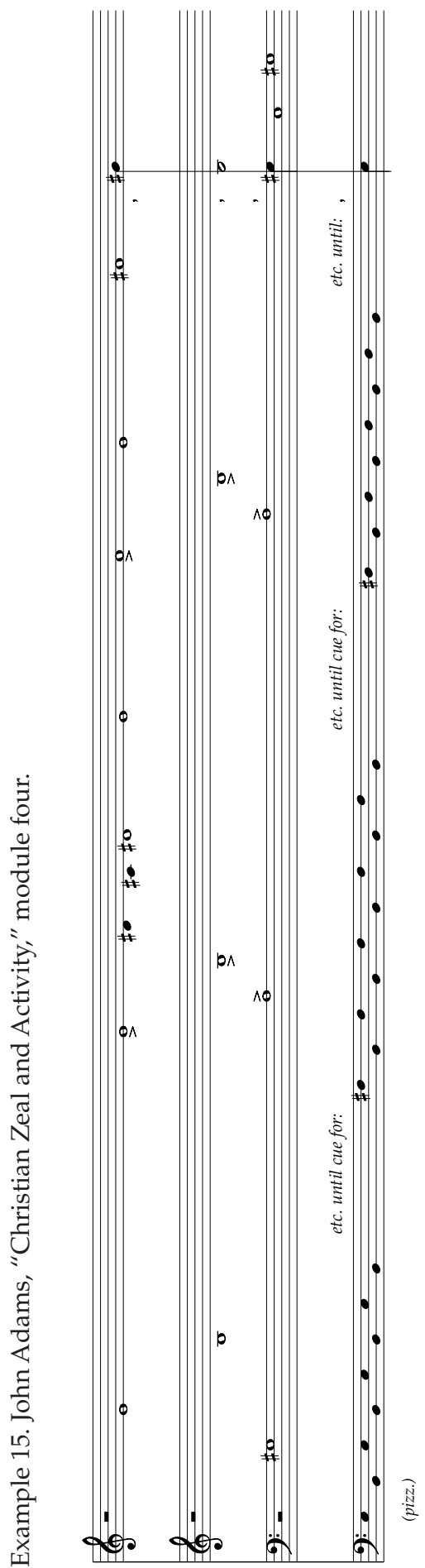


Christian Soldiers" with a radio debate between an atheist and a Christian fundamentalist (see the appendix for a transcription). The debate between the radio host and his caller gradually grows more and more heated until the host ends the discussion exasperated and demanding to not have any more calls on religion. Where one could intuit pathos, sentiment, or homage in Jesus' Blood Never Failed Me Yet, it would be difficult to perceive such sensibilities in "Christian Zeal and Activity." Adams favored an ironic and irreverent spin on Bryars's original idea.

\section{Composing in the Twilight}

Stephen Dedalus reappears in Joyce's Ulysses, his oft-quoted desire to escape from the "nightmare" of history suggesting the kinds of issues young composers like Adams faced in the postwar musical climate. The sheer number of compositional approaches one could adopt arose at a dizzying pace in the 1960s and 1970s and sometimes in conflict with one another. Cage, welcoming such diversity, would opine that artists found themselves without a mainstream; instead, there was a plurality of streams or even a delta or ocean in which all were adrift. ${ }^{66}$ At the same time, a growing preoccupation in the 1960s and 1970s with the weight of the Western art music tradition engendered a profound anxiety that was difficult to ease. These cultural contexts explain why we find the young Adams of the 1970s willing to embrace a seemingly disparate array of often conflicting aesthetic and compositional choices in a short period of time. They explain how he could so quickly switch from mimicking Cage and Stockhausen in Heavy Metal to writing a strange and clumsy composite work like Hockey Seen, which fuses popular music conventions, minimalist topics, and musique concrète. The overwhelming number of influences in Adams's mind as a young artist in the 1970s also explains why he would recycle Cagean influences with a work like Ktaadn and then abruptly shift to deconstructing vernacular music and using alternative notational schemes to experiment with indeterminacy in "Christian Zeal and Activity."

Minimalism is a recurring fixture within this diverse catalog of juvenilia. After "Christian Zeal and Activity," the story of Adams's attraction to minimalism continued with works such as Grounding (1975), a fiftyminute piece for live electronics involving an elaborate part for the composer's homemade synthesizer. Adams described this work as a "loosely structured process piece" that set passages from G. Spencer Brown's Laws of Form and Saraha's Treasury of Songs. ${ }^{67}$ Aside from the allusion to minimalist "process music" guiding the aesthetic of Grounding is the composer's prominent role as a synthesizer player, suggesting parallels with the ongoing do-it-yourself electronic music aesthetic most conspicuously exemplified by Terry Riley, Steve Reich, Philip Glass, and others. ${ }^{68}$ 
A final piece of juvenilia worth mentioning is Onyx (1976), a thirteenminute electronic work that also reflects Adams's early awareness of minimalism. Described by Adams as a four-channel "tape study," Onyx consists of shifting consonant triads performed on the composer's synthesizer alongside a perpetual accompaniment of buzzing cicadas. ${ }^{69}$ This obscure piece's unobtrusive quality arises from a lack of stark dynamic contrasts and from Adams's organizational approach. He structures the music according to large sections based on simple oscillating harmonic sequences among a compact gamut of pitch materials, eliding them with common-tone relations to obscure sectional breaks. The musical texture comes across as improvisatory, suggesting correspondences with contemporaneous electronic keyboard works disseminated by Riley and others during the 1970s.

These pieces of juvenilia demonstrate that there was never a neat or tidy break at which point Adams simply converted to the style with which he is now often associated. Yet in constructing his own narrative of compositional development, he frequently marked 1977 as the watershed year in which he composed his "official opus one," describing China Gates and Phrygian Gates as the "most strictly organized, rigorously ordered works I ever composed. They also demonstrated the fruits of my initiation to Minimalism. ${ }^{\prime 70}$ When did this initiation to minimalism actually begin? As the composer's juvenilia prior to 1977 indicates, a great deal of struggle took place with myriad avant-garde influences, and minimalism had been one of them at least five years before he produced a self-described "mature" composition. Although minimalism won out as Adams's preferred compositional approach, it only came about through several years of intensive experimentation.

\section{Appendix: John Adams, "Christian Zeal and Activity," Transcription of Radio Debate ${ }^{71}$}

DAvE: Hello, East Bay, you're on the air. Hello, line six?

CALLER: Good morning, Dave.

D: Good morning.

C: Good morning. Well, how man was created.

D: So what's your theory?

C: Well, according to the Bible, Adam and Eve are the original parents. They were the first two human beings that had intelligent, breathing - our minds and so on. The point is they were the first two intelligent human beings that were created by God in the Garden of Eden.

D: Now you say "according to the Bible."

C: Yes.

D: So you must be putting an awful lot of weight in the Bible, eh? 
C: Well, I believe that it's God's word and it's placed here for our use for the purposes of saving our souls and drawing us closer to God and revealing God's truth about his creation and future life and so forth.

D: What would you say to me if I told you I believe it's a book that was written by people long after the fact and sometimes with just a lot of distortions and everything else? Would you call me a heathen?

C: What?

D: If I said it was just a book?

C: Well it's more than a book. It's a masterpiece. It's the mind of God. It contains the mind of God-the state of man and the way of salvation and the happiness of believers. You see if you reject the word of God, then there is no hope at all for you. You might as well just put a gun to your temple and pull the trigger.

D: I don't think that's true.

C: Jump off a bridge. I mean, if you deny God and deny the fact that the Holy Bible is God's revelation to mankind, then-

D: Who is God? Is God a person to you?

C: God is the Supreme Being, the creator of the universe.

D: Yeah, but you're not telling me anything.

C: He's a spirit, he can't be seen, you know, with a human eye-the naked eye-but he exists. He's always been.

D: But he must be able to speak if that's the word of God.

$\mathrm{C}$ : Oh, you're able to contact him through prayer. If you're not able to reach him in any other way, it takes diligent Bible study and prayer. When a person becomes very ill physically or disturbed mentally in some way or a kind of misfortune where there is no possible help or aid for them or no way to find a solution to the problem, whatever it may be-it could be physical, it could be mental, it could be emotional, it could be financial, it could be something domestic, or something regarding a job or something where a person feels that prayer is a way of reaching our creator, our father.

D: Let me ask you a question sir.

C: Yes sir.

D: I don't have any financial problems. I don't think I have any physical or emotional problems. I'm not losing my job.

C: Mhmm.

D: So why do I need God then, if what you said is true?

C: Well, you see, it's necessary to, what we call, "be saved." There are "saved" individuals and there are "unsaved" people.

D: May I respectfully submit, sir, that, in other words, instead of saying "believing for me" is what you should say, because a 
belief is an invention. You're not going to tell me you have the answer.

C: Yes I do. You asked me your question-

D: No you don't. No sir. You don't have the answer for me any more than you can tell me what section of the city to live in. You can't tell me how to think.

C: You see, I'm a preacher and I read the Bible every day. And I pray from it and I read all the Scriptures.

D: Alright, but I don't care to have you preach to me. Do you follow me?

C: No, I don't mean that. I'm just saying that-

D: You're trying to convince of something but you're not convincing me.

C: Convince you, what? How to be sure-

D: You would convince me if you said, "God is for me. And this is the way I live."

C: God is for everyone, regardless of-

D: No he's not!

C: - -your nationality or your race or your color or your creed. He's the creator of all people.

D: Alright. I was just trying to teach you something in semantics, if I may be a little pedantic.

C: You've heard of the Psalms of David-King David in the Old Testament?

D: Hey, I don't want to get into a religious thing here now. Okay?

C: Don't get-

D: No, no, but that gets so boring. Look, I mean don't get into this stuff. This is not a forum. Bob, don't get me any more calls on religion, please.

\section{NOTES}

1. James Joyce, A Portrait of the Artist as a Young Man (New York: Penguin Book, 2016), 155.

2. Vicki Mahaffey, "Framing, Being Framed, and the Janus Faces of Authority," in James Joyce's "A Portrait of the Artist as a Young Man": A Casebook, ed. Mark Wollaeger (Oxford: Oxford University Press, 2003), 207. Joyce himself had extensive knowledge of and appreciation for music, with critics suggesting Wagnerian characters providing archetypical frames for the character of Stephen Dedalus. For more information on the view of Dedalus as a Siegfried-like character, see Timothy Martin, "Joyce, Wagner, and the Artist-Hero," Journal of Modern Literature 11, no. 1 (March 1984): 66-88. See also Martin, “Joyce, Wagner, and the Wandering Jew," Comparative Literature 42, no. 1 (Winter 1990): 49-72. Further suggesting influence from Wagner on Joyce's view of the artist as heroic is Vicki Mahaffey, “Wagner, Joyce, and Revolution," James Joyce Quarterly 25, no. 2 (Winter 1988): 237-47. A recent book-length examination of Joyce's intersections with music is Michelle Witen, James Joyce and Absolute Music (London: Bloomsbury, 2018). 
3. John Adams, Hallelujah Junction: Composing an American Life (New York: Farrar, Straus and Giroux, 2008), 86-87.

4. Ibid., 89. See also John Adams, "Sonic Youth: A Composer Finds His Voice in San Francisco," New Yorker, August 25, 2008.

5. Adams, Hallelujah Junction, 60.

6. This interview with Adams is publicly available in the digital archive set up by the Other Minds Archive, a nonprofit organization established by Charles Amirkhanian in 1992 that recently relocated its physical holdings to the University of California, Santa Cruz. For more information, see "About Other Minds," https:/ / www.otherminds.org/about/ (accessed March 10, 2017). See also Scott Rappaport, "Other Minds Donates Archives to UC Santa Cruz," https://news.ucsc.edu/2016/03/other-minds-archive.html (accessed March 10, 2017).

7. Adams, Hallelujah Junction, 60.

8. James Pritchett, The Music of John Cage (Cambridge: Cambridge University Press, 1993), 154-56. See also David Nicholls, "Towards Infinity: Cage in the 1950s and 1960s," in The Cambridge Companion to John Cage, ed. David Nicholls (Cambridge: Cambridge University Press, 2002), 106-8.

9. Adams, Hallelujah Junction, 60.

10. Jonathan Kramer, "Moment Form in Twentieth Century Music," Musical Quarterly 64, no. 2 (April 1978): 180. See also Gaël Tissot, "The First Electroacoustic Pieces by Karlheinz Stockhausen: Technologies and Aesthetics," Organized Sound: An International Journal of Music Technology 13, no. 3 (2008): 173-74.

11. Adams, Hallelujah Junction, 60.

12. An insightful overview of Hymnen can be found in Robin Maconie, Other Planets: The Complete Works of Karlheinz Stockhausen, 1950-2007 (New York: Rowman \& Littlefield, 2016), 249-56. See also Larson Powell, "The Technological Subject: Music, Media, and Memory in Stockhausen's Hymnen," in Sound Matters: Essays on the Acoustics of Modern German Culture, ed. Nora Alter and Lutz Koepnick (New York: Berghahn, 2004), 228-41.

13. A similar spatial element factors into a given realization of Cage's Variations $I V$ in terms of where sounds arise. For more information, see William Fetterman, John Cage's Theatre Pieces: Notations and Performances (New York: Routledge, 2010), 125-28.

14. Dean Lockwood, "Spread the Virus: Affective Prophecy in Industrial Music," in Sound, Music, Affect: Theorizing Sonic Experience, ed. Marie Thompson and Ian Biddle (New York: Bloomsbury, 2013), 126-27.

15. William Burroughs, The Electronic Revolution (Bonn: Expanded Media Editions, 1998), 27-28.

16. Cabaret Voltaire is one of the most conspicuous musical groups influenced by Burroughs's writing in the 1970s. For more information, see Simon Reynolds, "Living for the Future: Cabaret Voltaire, the Human League, and the Sheffield Scene," in Rip It Up and Start Again: Postpunk 1978-1984 (New York: Penguin Books, 2006), 89. For more information on Burroughs's own experimentation with tape, see Robin Lydenberg, "Sound Identity Fading Out: William Burroughs' Tape Experiments," in Wireless Imagination: Sound, Radio, and the Avant-Garde, ed. Douglas Kahn and Gregory Whitehead (Cambridge, MA: MIT Press, 1992), 409-38.

17. Douglas Kahn, Noise, Water, Meat: A History of Sound in the Arts (Cambridge, MA: MIT Press, 1999), 291.

18. John Adams, interviewed by Charles Amirkhanian, Ode to Gravity, aired April 18, 1973.

19. William Burroughs, Naked Lunch (New York: Grove Press, 1987), 95. For an explanation of how this passage relates to the larger themes of the narrator's relationship to the reader, see Anthony Hilfer, "Mariner and Wedding Guest in William Burroughs' Naked Lunch," Criticism 22, no. 3 (Summer 1980): 253-64.

20. Adams interviewed by Charles Amirkhanian, April 18, 1973. 
21. Todd Tietchen, "Language Out of Language: Excavating the Roots of Culture Jamming and Postmodern Activism from William S. Burroughs' Nova Trilogy," Discourse 23, no. 3 (Fall 2001): 110, 113. See also Brent Wood, "William S. Burroughs and the Language of Cyberpunk," Science Fiction Studies 23, no. 1 (March 1996): 14-15.

22. For more information, see Daniel Belgrad, The Culture of Spontaneity: Improvisation and the Arts in Postwar America (Chicago: University of Chicago Press, 1998), 253-54.

23. Fiona Paton, "Monstrous Rhetoric: Naked Lunch, National Insecurity, and the Gothic Fifties," Texas Studies in Literature and Language 52, no. 1 (Spring 2010): 54.

24. William Burroughs, The Soft Machine (New York: Grove Press, 1992), 178. John Adams's roommate in Cambridge, Massachusetts, recited the text heard in Heavy Metal in a manner that deliberately sounds like the voice of Burroughs. Adams mentioned this aspect of the compositional process in the 1973 interview: "I roused him out of bed at about eight o'clock one morning when I had the studio and he croaks in a fashion very much like Burroughs."

25. Adams interviewed by Vincent Plush, May 23, 1983, Major Figures in American Music, 32, https://web.library.yale.edu/music/oham.

26. V. A. Howard, "Project Zero: A Fresh Look at Art Education," Bulletin of the Council for Research in Music Education, no. 21 (Summer 1970): 1. For information on the cultural climate of the 1960s regarding education in the United States following the launch of Sputnik, see Howard Gardner, "Project Zero: Nelson Goodman's Legacy in Arts Education," Journal of Aesthetics and Art Criticism 58, no. 3 (Summer 2000): 245-46.

27. I mention this curious phrase, "electronic score," because it is described that way by the collaborators. No physical score of the music composed for Hockey Seen exists. All musical examples provided are transcriptions made by the author.

28. Adams interviewed by Charles Amirkhanian, April 18, 1973.

29. John Adams interviewed by Vincent Plush, 33. For a brief discussion of Hockey Seen by Nelson Goodman, see Of Mind and Other Matters (Cambridge, MA: Harvard University Press, 1984), 69-71.

30. Nelson Goodman, Ways of Worldmaking (Indianapolis, IN: Hackett Publishing Company, 1978), 102.

31. John Adams interviewed by Vincent Plush, 33.

32. Adams interviewed by Charles Amirkhanian, April 18, 1973.

33. Ibid.

34. For more information on the album release and "Baba O'Riley," see Chris Charlesworth and Ed Hanel, "Who's Next: August 1971," in 25 Albums That Rocked the World (London: Omnibus Press, 2011), 80-84.

35. Adams, Hallelujah Junction, 40.

36. Adams interviewed by Charles Amirkhanian, April 18, 1973.

37. For an in-depth account of the reception history of Hockey Seen in the 1970s, see Curtis Carter, "Nelson Goodman's Hockey Seen: A Philosopher's Approach to Performance," in Congress Book 2: Selected Papers: XVIIth International Congress of Aesthetics, ed. Jale Erzen (Ankara: METU Faculty of Architecture, 2009), 65. For contemporaneous reviews of Hockey Seen, see Daniel Webster, "Goal Is Reached in Hockey Seen," Philadelphia Inquirer, November 4, 1973. See also Daniel Webster, "Dancers Portray Hockey as a Game of Beauty, Grace," Philadelphia Inquirer, November 8, 1973.

38. John Adams to Nelson Goodman, San Francisco, August 18, 1979, quoted in Curtis Carter, Hockey Seen: A Nightmare in Three Periods and Sudden Death: A Tribute to Nelson Goodman (Milwaukee, WI: Patrick and Beatrice Haggerty Museum, 2006), 8-9.

39. John Adams interviewed by Vincent Plush, 33.

40. It is likely that the specific model Adams used for composing Hockey Seen was the ARP 2600 synthesizer, which Adams mentions in both his 1973 interview with Amirkhanian and 1983 interview with Plush. For more information on the ARP 2600 synthesizer's history, see Trevor Pinch and Frank Trocco, Analog Days: The Invention and Impact of the 
Moog Synthesizer (Cambridge, MA: Harvard University Press, 2002), 261-71. See also Mark Jenkins, Analog Synthesizers: Understanding, Performing, Buying — from the Legacy of Moog to Software Synthesis (Burlington, MA: Focal Press, 2007), 60-63.

41. For a general history of synth-pop's relationship with popular music, particularly during the 1970s and into the 1980s, see Nicholas Collins, Margaret Schedel, and Scott Wilson, Electronic Music (Cambridge: Cambridge University Press, 2013), 90-101.

42. The original New York Times Review recounts that there were audible boos. For more information, see John Rockwell, "Concert: New Music of California," New York Times, June 6, 1983. See also John Rockwell, "Is 'New Romanticism' Music of the Future?," New York Times, June 16, 1983.

43. Adams, Hallelujah Junction, 84. Adams may have also attended a John Cage concert held in the Slosberg Recital Hall at Brandeis University on November 21, 1969.

44. For more information, see David Ingram, "'The Clutter of the Unkempt Forest': John Cage, Music and American Environmental Thought," American Studies 51, no. 4 (2006): 567-79. See also Benjamin Piekut, "Chance and Certainty: John Cage's Politics of Nature," Cultural Critique 84 (Spring 2013): 142-43. For a book-length study of the intersections between Cage's Zen Buddhism and ecological outlook, see Peter Jaeger, John Cage and Buddhist Ecopoetics (London: Bloomsbury, 2013). Also relevant is Jack Miles, "Global Requiem: The Apocalyptic Moment in Religion, Science, and Art," CrossCurrents 50, no. 3 (Fall 2000): 304-5.

45. John Cage, Song Books: Volume I (New York: C. F. Peters, 1970), 2-6.

46. Thoreau himself had noted and provided definitions for several of the Abenaki words he encountered on his journey. For a listing, see Henry David Thoreau, The Maine Woods (New York: Houghton Mifflin Company, 1893), 430-35. Adams consulted Thoreau's text for aid in translating some of the words he found and also drew upon George Stewart's 1970 compendium A Dictionary of American Place Names.

47. John Adams interviewed by Vincent Plush, 48-49.

48. John Adams, Ktaadn (San Francisco: Saxonia Music, 1974).

49. The modality of Ktaadn offers one clear example of Adams refashioning an element from his experimental practices to fit within his newly adopted minimalist language. China Gates and Phrygian Gates are the most obvious results of this development, with their explicitly modal conception. The conspicuous repetition found in Ktaadn is similarly a latent minimalist feature that Adams would explore to great effect in the late 1970s and early 1980s.

50. The tempo Adams set for Ktaadn is. ' = 104-32.

51. John Adams, epigraph included in performance notes for the photocopy of the composer's manuscript of Ktaadn, 1974, John Adams Papers, San Francisco Conservatory of Music Library, San Francisco, CA. The published edition of Ktaadn, for unknown reasons, does not include this quote.

52. John Neff and Howard Whitcomb, Baxter State Park and Katahdin (Charleston, SC: Arcadia Publishing, 2012), 9-10.

53. Adams, "Sonic Youth."

54. George Kauffman, "Visions and Voices in Space," Berkeley Barb, May 24-30, 1974.

55. Adams interviewed by Charles Amirkhanian, April 18, 1973.

56. For more information on the historiography of Ives criticism and reception from the 1950s, 1960s, and early 1970s, see David Paul, Charles Ives in the Mirror: American Histories of an Iconic Composer (Urbana: University of Illinois Press, 2013), 72-110.

57. Adams interviewed by Charles Amirkhanian, April 18, 1973.

58. Michael Hicks and Christian Asplund, Christian Wolff (Urbana: University of Illinois Press, 2012), 46-48.

59. John Adams, liner notes to Ensemble Pieces, San Francisco Conservatory New Music Ensemble, Obscure Records 2, LP, 1975. Most intriguing about American Standard is that Adams includes what he deems optional "extra materials," such as film, tape, video, 
speech, mime, and dance. In this particular LP, the first movement utilizes a snare drum roll, the second incorporates a radio talk show, and the third employs a trap set. Writing in 1992, Fritz Hennenberg described this work as involving a kind of "musical documentary style" cultivated by the inclusion of these extra sound elements. For more information, see Hennenberg, "Zurück und in die Zukunft: Anmerkungen zu John Adams," Neue Zeitschrift für Musik 153, no. 3 (1992): 24.

60. For more information, see Philip Thomas and Stephen Chase, Changing the System: The Music of Christian Wolff (Burlington, VT: Ashgate, 2010), 179-84. See also Hicks and Asplund, Christian Wolff, 60-63.

61. Christian Wolff, Cues: Writing and Conversations (Cologne: Edition MusikTexte, 1998), 352.

62. For more information, see Brett Boutwell, “'The Breathing of Sound Itself': Notation and Temporality in Feldman's Music to 1970," Contemporary Music Review 32, no. 6 (2013): 548-57.

63. Adams revealed in 1983 that he commissioned Wild Lilies Bloom Red as Flame from Cardew. For more information, see John Adams interviewed by Vincent Plush, 19-20.

64. To hear Amirkhanian's complete review of this concert on KPFA, see http:/ / radiom. org/detail.php?et=interviewMusic\&omid=AM.1974.03.22.c1 (accessed June 9, 2017).

65. Cecilia Sun, "Experiments in Musical Performance: Historiography, Politics, and the Post-Cagean Avant-Garde" (PhD diss., University of California, Los Angeles, 2004), 107-8, $111-12$.

66. For more information, see Mark Hutchinson, "Introduction: Beyond the Delta?," in Coherence in New Music: Experience, Aesthetics, Analysis (London: Routledge, 2016), 1-22.

67. Adams, Hallelujah Junction, 72. Information is also found in Adams interviewed by Vincent Plush, 50.

68. Adams interviewed by Vincent Plush, 50. Reich built his Phase Shifting Pulse Gate between February 1968 and the first months of 1969 with help from engineers at the Bell Laboratories. It has been described in meticulous technical detail by Reich and was unveiled in May 1969 with a performance of Pulse Music, written specifically for the new instrument. For Reich's description of the background surrounding the building of this device, see Writings on Music: 1965-2000, ed. Paul Hillier (Oxford: Oxford University Press, 2002), 38-41. See also K. Robert Schwarz, "Steve Reich: Music as a Gradual Process Part II," Perspectives of New Music 20, no. 1/2 (Autumn 1981 / Summer 1982): 227-29.

69. Adams, Hallelujah Junction, 87. For a review of a public performance of Onyx, see Clifford Barnes, "Currents Electronic Music Series at Theater Vanguard," Los Angeles Times, December 6, 1977.

70. Adams, Hallelujah Junction, 89. See also Adams, "Sonic Youth."

71. This transcription was written by the author and was made possible by accessing the complete broadcast of American Standard that was part of the April 1973 interview of Adams on KPFA. To hear the complete broadcast, which is accessible through the Other Minds Digital Archive, go to http:/ / radiom.org/detail.php?omid=OTG.1973.04.18.A (accessed June 9, 2017). 